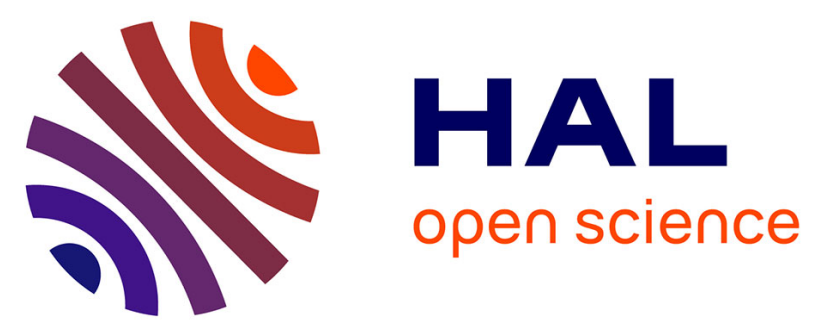

\title{
Ecological tracers and at-sea observations document the foraging ecology of southern long-finned pilot whales (Globicephala melas edwardii) in Kerguelen waters
}

Marina Fontaine, Alice Carravieri, Benoit Simon-Bouhet, Paco Bustamante, Nicolas Gasco, Frédéric Bailleul, Christophe Guinet, Yves Cherel

\section{To cite this version:}

Marina Fontaine, Alice Carravieri, Benoit Simon-Bouhet, Paco Bustamante, Nicolas Gasco, et al.. Ecological tracers and at-sea observations document the foraging ecology of southern long-finned pilot whales (Globicephala melas edwardii) in Kerguelen waters. Marine Biology, 2015, 162, pp.207-219. 10.1007/s00227-014-2587-3 . hal-01150197

\author{
HAL Id: hal-01150197 \\ https://hal.science/hal-01150197
}

Submitted on 11 May 2015

HAL is a multi-disciplinary open access archive for the deposit and dissemination of scientific research documents, whether they are published or not. The documents may come from teaching and research institutions in France or abroad, or from public or private research centers.
L'archive ouverte pluridisciplinaire HAL, est destinée au dépôt et à la diffusion de documents scientifiques de niveau recherche, publiés ou non, émanant des établissements d'enseignement et de recherche français ou étrangers, des laboratoires publics ou privés. 
Ecological tracers and at-sea observations document the foraging ecology of southern long-finned pilot whales (Globicephala melas edwardii) in Kerguelen waters

\section{Marina Fontaine - Alice Carravieri - Benoit Simon-Bouhet - Paco Bustamante - Nicolas Gasco - Frederic Bailleul Christophe Guinet - Yves Cherel}

M. Fontaine-- A. Carravieri - F. Bailleul -. C. Guinet - Y. Cherel

Centre d'Etude Biologique de Chizé, CNRS UPR 1934

79360 Villiers en Bois, France

Marina.fontain@gmail.com

A. Carravieri - B. Simon-Bouhet - P. Bustamante

Littoral Environnement et Sociétés (LIENSs), UMR 7266 CNRS-Université La Rochelle, 2 rue Olympe de Gouges, F-17000 La Rochelle Cedex, France

N. Gasco

Département des milieux et peuplements marins

UMS 403 du Muséum d'Histoire Naturelle de Paris

43, rue Cuvier, 75231 Paris Cedex 05, France 


\begin{abstract}
:
The food and feeding ecology of the poorly known southern long-finned pilot whale (Globicephala melas edwardii) was investigated using ecological tracers (muscle and skin $\delta^{13} \mathrm{C}$ and $\delta^{15} \mathrm{~N}$, and total mercury, $\mathrm{Hg}$ ) on individuals from two mass strandings together with at-sea observations of live animals in Kerguelen waters, southern Indian Ocean. Sightings of cetaceans from long-liners over 9 years (2003-2012) emphasized the regular occurrence of pilot whales in slope waters surrounding the archipelago. Tissue $\delta^{13} \mathrm{C}$ values (a proxy of consumer foraging habitat) suggest that pilot whales fed in slope waters and in oceanic subantarctic waters over the last months preceding stranding. Tissue $\delta^{15} \mathrm{~N}$ values and $\mathrm{Hg}$ concentration (dietary proxies) indicate a high trophic position ( 4.7) for the pilot whales, likely corresponding to a mixed diet of fish and squid (not crustaceans) of undetermined species. Both skin and muscle $\mathrm{Hg}$ concentrations were positively and linearly correlated to individual size with no concomitant $\delta^{15} \mathrm{~N}$ changes, which can be interpreted as a progressive $\mathrm{Hg}$ accumulation in tissues of individuals throughout life with no parallel dietary shift. Skin and muscle $\mathrm{Hg}$ concentrations were linearly and positively related; hence, $\mathrm{Hg}$ skin could be used as a proxy of $\mathrm{Hg}$ concentration in muscle (a main $\mathrm{Hg}$ reservoir of the body). Kerguelen southern long-finned pilot whales were less $\mathrm{Hg}$ contaminated than most pilot whale populations studied so far, thus suggesting that they are not at a high risk to $\mathrm{Hg}$-induced damages in the remote islands of the Southern Ocean.
\end{abstract}

Keywords: stable isotopes; mercury; marine mammal 


\section{Introduction}

Understanding the role of cetaceans in the structure and functioning of ecosystems is directly linked to a better knowledge of their foraging ecology that is often difficult to assess in the marine environment (Bowen 1997). Unlike breeding pinnipeds that can be handled ashore, cetaceans remain at sea all life long and, hence, investigating the food and feeding ecology of free-ranging odontocetes and mysticetes is especially challenging. Alternatively, mass stranding events offer a unique opportunity to collect large sets of biologically relevant data from dead specimens. Pilot whales (Genus Globicephala) are one of the most frequently reported cetaceans in mass strandings (Olson 2009). Two species of pilot whales are recognized: the short- and long-finned pilot whales (G. macrorhynchus and G. melas, respectively), with the latter species including two spatially segregated subspecies, namely $G$. m. melas in the North Atlantic and G. m. edwardii in the Southern Ocean (Olson 2009; Oremus et al. 2009). The overall biology of the northern subspecies is well known, e.g. mortality rate, life span (longevity up to 59 and 46 years in females and males, respectively) and adult length (up to 5.1 and $6.3 \mathrm{~m}$ in females and males) (Donovan et al. 1993). By contrast, the biology, including the food and feeding habits of the southern subspecies, is poorly documented. Dietary investigations on the southern long-finned pilot whale focused primarily on stomach content analysis of a few stranded individuals from Tasmania (Gales et al. 1992), New Zealand (Beatson et al. 2007a, b; Beatson and O'Shea 2009), Tierra del Fuego (Goodall and Galeazzi 1985; Clarke and Goodall 1994; Mansilla et al. 2012) and Brazil (dos Santos and Haimovici 2001), with no available information from the southern Indian Ocean. Cephalopods form the bulk of the food, but stomach content examination of stranded individuals suffers several drawbacks including overestimation of prey with hardly digestible elements that accumulate over time (e.g. cephalopod beaks), a bias towards the presence of near shore prey species, and the unknown health status of the animals (Santos et al. 2001).

Indirect trophic methods have been developed over the last 25 years to complement more conventional means. These methods use 'ecological tracers', such as stable isotopes, lipids and contaminants, and are all based on the common principle 'you are what you eat', i.e. the biochemical composition of molecules and tissues of consumers reflects that of their food in a predictable manner (Ramos and Gonzalez-Solis 2012). Stable isotope ratios of carbon $\left(\delta^{13} \mathrm{C}\right)$ and nitrogen $\left(\delta^{15} \mathrm{~N}\right)$ are increasingly popular to investigate the ecology of terrestrial and marine organisms. $\delta^{13} \mathrm{C}$ values vary little along the food chain and are mainly used to determine primary sources in a trophic network (Kelly 2000; McCutchan et al. 2003). In the marine 
environment, $\delta^{13} \mathrm{C}$ values indicate consumer foraging areas (i.e. inshore versus offshore and pelagic versus benthic) or latitudinal variation in the contribution to food intake (Hobson et al. 1994, Cherel et al. 2000a; Pajuelo et al. 2012). In contrast, consumer tissues are enriched in ${ }^{15} \mathrm{~N}$ relative to their food and $\delta^{15} \mathrm{~N}$ values are used as indicators of consumers' trophic positions (McCutchan et al. 2003; Vanderklift and Ponsard 2003). A main interest of the isotopic method is that $\delta^{13} \mathrm{C}$ and $\delta^{15} \mathrm{~N}$ values provide dietary information over different temporal scales depending on tissue-specific isotopic turnover rates that range from a few days for plasma to several years for bone collagen (Dalerum and Angerbjörn 2005; Newsome et al. 2010).

Mercury $(\mathrm{Hg})$ concentration can also be used as a biomarker of dietary preferences and trophic positions of consumers because the main source of $\mathrm{Hg}$ contamination is food and $\mathrm{Hg}$ biomagnifies along food webs, meaning that $\mathrm{Hg}$ level increases with increasing trophic position of consumers within a given ecosystem (Gray 2002; Ramos and Gonzalez-Solis 2012). Hg derives from both natural and anthropogenic sources. Owing to its high volatility and long atmospheric residence time, $\mathrm{Hg}$ reaches remote areas through long-range atmospheric transport, thus contaminating oceanic islands and Polar Regions (Fitzgerald et al. 1998). Hg levels vary with the marine environments, being enhanced in coastal waters relative to the surface ocean, higher at depths relative to oceanic surface waters and depending on oceanic water masses (Fitzgerald et al. 2007; Cossa et al. 2011). In addition, Hg is a persistent, toxic and highly mobile metal in the marine environment. In mammals, $\mathrm{Hg}$ toxicity is primarily manifested as central nervous system damage including sensory and motor deficits and behavioural impairments. Reliable toxicity data for marine mammals are scarce, but the slow rate of contaminant elimination and high contaminant levels of cetaceans make them good sentinel species for the monitoring of ecosystem health (Das et al. 2003).

Using a combination of visual observations from fishing vessels together with stable isotopes and $\mathrm{Hg}$ from tissues of stranded animals as ecological tracers, the main aim of this exploratory study was to investigate the food and feeding ecology of southern long-finned pilot whales in a remote archipelago (Kerguelen), where almost nothing is known about the species. Only a few records of pilot whales have been documented in the southern Indian Ocean, including Kerguelen waters (Robineau 1989; Robineau and Duhamel 2006). The isotopic method was validated in the area, with $\delta^{13} \mathrm{C}$ values of predators indicating their foraging habitats (Cherel and Hobson 2007; Jaeger et al. 2010) and their $\delta^{15} \mathrm{~N}$ values increasing with trophic level (Cherel et al. 2010). In brief, $\delta^{13} \mathrm{C}$ values decrease from inshore to offshore consumers and they decrease with increasing oceanic latitudinal foraging habitats of the predators, while $\delta^{15} \mathrm{~N}$ values increase in the order crustacean-eaters $<$ small fish consumers $<$ large fish and squid 
consumers. The pilot whale isotopic niche was determined using two tissues that record trophic information at different time scales, with skin and muscle integrating periods of weeks and months, respectively (Browning et al. 2014, Newsome et al. 2010). Previous and ongoing investigations on $\mathrm{Hg}$ exposure showed a large range of $\mathrm{Hg}$ concentrations within marine organisms living in Kerguelen waters that indicates $\mathrm{Hg}$ biomagnification in the corresponding oceanic ecosystem (Bustamante et al. 2003a; Bocher et al. 2003; Blévin et al. 2013; Carravieri et al. 2013, 2014). Ontogeny, age and sex modulates the foraging ecology, and thus the isotopic signature of cetaceans (Das et al. 2004; Nino-Torres et al. 2006; Newsome et al. 2009), and feeding habits, age, size and sex affect their Hg levels (Das et al. 2003; Lahaye et al. 2006). Hence, influences of individual traits (sex and size) on foraging habitat $\left(\delta^{13} \mathrm{C}\right)$ and trophic position $\left(\delta^{15} \mathrm{~N}\right)$ as well as influences of both individual traits and foraging ecology on $\mathrm{Hg}$ concentrations were examined on a fairly large numbers of southern long-finned pilot whales that stranded in 2006 and 2010 at Kerguelen Islands.

\section{Materials and methods}

\section{At-sea observations}

Sightings of cetaceans were recorded by fishery observers working on-board seven French long-liners that fished within the Exclusive Economic Zone off Kerguelen Islands. The fishery targets the Patagonian toothfish (Dissostichus eleginoides) in slope waters (500-2,500 m depths) surrounding the archipelago. Observers recorded the occurrence, number and location (longitude and latitude) of any cetacean found in the area. Then, the geo-referenced data were included into the Pecheker data base (Martin and Pruvost 2007). All the pilot whale records during the period 2003-2012 were extracted from the data base and the software R.2.15.3 ('base', 'RcolorBrewer' and 'fields'; R Development Core Team 2013) was used to build a repartition map of the species in Kerguelen waters (Fig. 1). Bathymetric data around the Kerguelen Plateau were extracted from the General Bathymetric Chart of the Oceans (GEBCO) at the British Oceanographic Data Centre (BODC) website.

\section{Study sites, stranding events and tissue sampling}

Fieldwork was carried out at Kerguelen Islands (southern Indian Ocean), which is located in the southern part of the Polar Frontal Zone, in the immediate vicinity of the Polar Front (Park and Gambéroni 1997). Two mass strandings of 91 and 135 southern long-finned pilot whales occurred on remote beaches of the Courbet Peninsula ( $\left.49^{\circ} 21^{\prime} \mathrm{S}, 70^{\circ} 18^{\prime} \mathrm{E}\right)$ in October 2006 and 
January 2010, respectively. The precise dates of the two events are unknown. Noticeably, most internal organs from the carcasses were already scavenged by seabirds, thus precluding the collection of stomach contents, and hence, direct dietary analysis. All the specimens but four ( $n=222$ ) were measured (total length, TL). Small individuals with TL $\leq 3.0 \mathrm{~m}$ were considered as suckling calves as the average (maximum) TL at the onset of weaning are 2.2 (3.2) and 2.2 (3.5) $\mathrm{m}$ for females and males, respectively (Desportes and Mouritsen 1993). Tissue sampling was performed on 193 specimens ( $n=91$ and 102 in 2006 and 2010, respectively). Both skin and muscle samples were collected from most pilot whales $(n=137)$, but some specimens were sampled for skin or muscle alone ( $n=29$ and 27, respectively). Tissue samples were either stored in $70 \%$ ethanol (2006) or kept frozen at $-20{ }^{\circ} \mathrm{C}(2010)$ until laboratory analyses in France.

\section{Stable isotopes, mercury and molecular sexing}

Any remain of subcutaneous white adipose tissue was removed from skin samples with a scalpel. The 2006 skin and muscle samples were first oven dried at $50{ }^{\circ} \mathrm{C}$ for $48 \mathrm{~h}$ for ethanol evaporation. Then, samples from both years were freeze-dried during $48 \mathrm{~h}$ and then grinded in a mortar. Since lipids are depleted in ${ }^{13} \mathrm{C}$ relative to other tissue components (DeNiro and Epstein 1977), they were extracted from skin and muscle samples using cyclohexane following Chouvelon et al. (2011). Powdered subsamples were weighed (0.3-0.4 mg) with a microbalance and packed into tin containers. Relative abundance of carbon $\left({ }^{13} \mathrm{C} /{ }^{12} \mathrm{C}\right)$ and nitrogen $\left({ }^{15} \mathrm{~N} /{ }^{14} \mathrm{~N}\right)$ were determined with a continuous flow mass spectrometer (Micromass Isoprime) coupled to an elemental analyser (Euro Vector EA 3024). Results are presented in the usual $\delta$ notation (in \%o) relative to Vienna PeeDee Belemnite and atmospheric $\mathrm{N}_{2}$ for $\delta^{13} \mathrm{C}$ and $\delta^{15} \mathrm{~N}$, respectively. Replicate measurements of internal laboratory standards (acetanilide) indicated measurement errors $<0.15 \%$ for both $\delta^{13} \mathrm{C}$ and $\delta^{15} \mathrm{~N}$ values.

Between 5 and $15 \mathrm{mg}$ of freeze-dried and powdered samples were analysed in an advanced $\mathrm{Hg}$ analyser spectrophotometer (Altec AMA 254) following Bustamante et al. (2006). Hg determination involved evaporation of $\mathrm{Hg}$ by progressive heating until $800{ }^{\circ} \mathrm{C}$ under oxygen atmosphere for $2 \mathrm{~min} 30 \mathrm{~s}$ and subsequent amalgamation on a gold trap. The net was heated to liberate the collected $\mathrm{Hg}$ that was measured by UV atomic absorption spectrophotometry. Samples were analysed for total $\mathrm{Hg}$. All analyses were repeated 2-3 times until having a relative standard deviation $<10 \%$. Accuracy was checked using certified reference material [Tort-2 Lobster Hepatopancreas, NRC, Canada; mean $0.27 \pm 0.06 \mu \mathrm{g} \mathrm{g}^{-1}$ dry weight (dw)]. Our 
measured values were $0.29 \pm 0.02 \mu \mathrm{g} \mathrm{g} \mathrm{g}^{-1} \mathrm{dw}(n=56)$. Blanks were analysed at the beginning of each set of samples and the detection limit of the method was $0.005 \mu \mathrm{g} \mathrm{g}^{-1} \mathrm{dw}$.

Sampled individuals were sexed genetically using polymerase chain reaction (PCR) of introns within the Zfx and Zfy genes (Shaw et al. 2003). DNA was extracted and purified from a 25 $\mathrm{mg}$ aliquot of skin with the extraction kit 'NucleoSpin ${ }^{\circledR}$ Tissue'. PCR was performed on purified DNA ranging from 0.1 to $136 \mathrm{ng}$ in a $20 \mu \mathrm{l}$ reaction volume containing $12.5 \mu \mathrm{l}$ of pure water, $2 \mu \mathrm{l}$ of $1 *$ Taq polymerase reaction buffer, $1.5 \mu \mathrm{M} \mathrm{MgCl} 2,150 \mu \mathrm{M}$ dNTPs, $1.5 \mathrm{U}$ of Taq polymerase (Invitrogen) and either $0.3 \mu \mathrm{M}$ of primers ZFX0582 forward, ZFX0928 reverse (for Zfx/Zfy amplification) and SRY reverse or $0.06 \mu \mathrm{M}$ of primer SRY forward (for SRY amplification, Rosel 2003). PCRs were performed as follows: 1 cycle for $30 \mathrm{~s}$ at $92{ }^{\circ} \mathrm{C}$, then 35 cycles of denaturation for $30 \mathrm{~s}$ at $94{ }^{\circ} \mathrm{C}$, annealing for $45 \mathrm{~s}$ at $51{ }^{\circ} \mathrm{C}$ and amplification for $45 \mathrm{~s}$ at $72{ }^{\circ} \mathrm{C}$. Then, each sample was loaded on a $3 \%$ agarose gel and the fragments were separated by electrophoresis. Zfx-/Zfy-specific primers (Online Resource 1) allowed differentiating males ( 2 bands, 339 basepairs (bp) for the X-specific band and $382 \mathrm{bp}$ for the Y-specific fragment) from females (1 band).

\section{Methodological issue and statistical analyses}

Since the precise dates of the two stranding events were unknown, the effect of the 'quality' of the skin samples was visually assessed. Samples were considered either 'bad' if skin was altered and not easily differentiable from the subcutaneous connective tissue or 'good' if skin was easily differentiable. The influence of sample quality on skin $\delta^{13} \mathrm{C}, \delta^{15} \mathrm{~N}$ and $\mathrm{Hg}$ values within each stranding event was tested with Welch's t tests using R.2.15.3 ('stats'). In both 2006 and 2010, skin samples of bad quality had significantly higher $\delta^{13} \mathrm{C}$ and $\delta^{15} \mathrm{~N}$ values and significantly lower Hg values than good quality samples (Online Resource 2).

Muscle samples were then grouped according to the corresponding quality of skin samples and an identical quality effect was found for $\delta^{15} \mathrm{~N}$ and $\mathrm{Hg}$ values but not for $\delta^{13} \mathrm{C}$ values in 2010 samples. In contrast, no significant differences between muscle samples of good and bad quality were found in 2006. Consequently, $\delta^{13} \mathrm{C}, \delta^{15} \mathrm{~N}$ and $\mathrm{Hg}$ values from good 2006 and 2010 skin samples, all 2006 muscle $\delta^{13} \mathrm{C}, \delta^{15} \mathrm{~N}$ and $\mathrm{Hg}$ values, all 2010 muscle $\delta^{13} \mathrm{C}$ values, but only $\delta^{15} \mathrm{~N}$ and $\mathrm{Hg}$ values from good 2010 muscle samples were used for statistical analyses (Table 1).

Welch's $t$ tests (two-sample unpooled $t$ tests for unequal variances) were used to check if the two tissues (skin and muscle) differed or not in various parameters $\left(\delta^{13} \mathrm{C}, \delta^{15} \mathrm{~N}\right.$ and $\left.\mathrm{Hg}\right)$. The influence of size (TL), sex and year of stranding on $\delta^{13} \mathrm{C}, \delta^{15} \mathrm{~N}$ and $\mathrm{Hg}$ values were investigated using generalized linear models (GLMs) using R.2.15.3 ('stats'). In models where Hg 
concentrations were the response variable, $\delta^{13} \mathrm{C}$ (but not $\delta^{15} \mathrm{~N}$ values, see 'Results') was also incorporated as an explanatory variable. Models were constructed by incorporating the different variables and biologically significant interactions. Correlations between explanatory variables were tested using Pearson's correlation tests. The most parsimonious models were selected through forward selection according to the bias-adjusted Akaike's Information Criterion (AICc), which is a small sample size adjustment (Akaïke 1973; Burnham and Anderson 2002). As a general guideline, if AICc values differ by more than 2, the model with the lowest AICc value is the most accurate, whereas models with AICc values differing by less than 2 are fairly similar in their ability to describe the data, and the model including the least number of parameters (the simplest) is the most accurate (Lebreton et al. 1992). Residuals of selected models were checked for normality using Shapiro-Wilk test and Q-Q plots. The explained variation is reported for each model (Table 2). The relationship between $\mathrm{Hg}$ concentrations in skin and muscle was best described by a linear model. Values are mean \pm SD.

\section{Results}

\section{At-sea observations}

A total of 131 at-sea observations of southern long-finned pilot whales were recorded within the Kerguelen Exclusive Economic Zone during the period from 31 October 2003 to 12 December 2012 ( $~ 9$ years). The number of individuals per sighting averaged 53 individuals and ranged from 1 to $\sim 300$ individuals. The resulting map (Fig. 1) highlights the presence of the species in slope waters surrounding the Kerguelen Archipelago. Seasonal differences between winter and summer were found neither in pilot whale repartition nor in differences in the number of their at-sea observations (weighted by fishing effort that was quantified using the number of hooks).

\section{Stranded individuals}

TL of stranded southern long-finned pilot whales averaged $4.2 \pm 1.1 \mathrm{~m}$ with no significant differences between the 2 years (Welch's $t$ test, $t=0.22, p=0.826$ ). TL ranged from 1.6 to 6.9 $\mathrm{m}$ with a mode at 4-5 $\mathrm{m}$ (Fig. 2), which corresponds to the size range of the species (Bloch et al. 1993a, b). Skin and muscle $\delta^{13} \mathrm{C}, \delta^{15} \mathrm{~N}$ and $\mathrm{Hg}$ values during the 2 years are presented in Table 1. In 2006, $\delta^{13} \mathrm{C}$ and $\delta^{15} \mathrm{~N}$ values were significantly lower in muscle than in skin, while $\mathrm{Hg}$ concentration was higher in muscle $(t=-12.32,-10.68$ and 5.12, respectively, all $p<$ 
0.0001). In 2010, $\delta^{13} \mathrm{C}$ value was again lower in muscle $(t=-5.21, p<0.0001)$, but $\delta 15 \mathrm{~N}$ values of the two tissues were not statistically different and $\mathrm{Hg}$ concentration was higher in skin than in muscle $(t=-2.93, p<0.010)$. A statistical comparison of the 2 years showed that skin $\delta^{13} \mathrm{C}$ values, but not skin $\delta 15 \mathrm{~N}$ and $\mathrm{Hg}$ values, were different $(t=5.16, p<0.0001)$, and that muscle $\delta^{13} \mathrm{C}, \delta^{15} \mathrm{~N}$ and $\mathrm{Hg}$ values were all significantly different between 2006 and $2010(t=5.96$, 3.59 and $10.19, p<0.0001,<0.01$ and $<0.0001$, respectively).

Statistical analyses of the influence of individual traits (sex and TL) and year of stranding on isotopic values (Table 2) showed that the most parsimonious GLM selected by AICc values included the effect of year in explaining tissue $\delta^{13} \mathrm{C}$ values, with $\delta^{13} \mathrm{C}$ values being significantly higher in 2006 than in 2010 (see above). Skin $\delta^{15} \mathrm{~N}$ values were best explained by an effect of sex, TL and year, and muscle $\delta^{15} \mathrm{~N}$ values by an effect of TL and year. Tissue $\delta^{15} \mathrm{~N}$ values decreased with increasing TL in small individuals $(\leq 3 \mathrm{~m})$, but did not change with increasing TL in mature individuals ( $>3 \mathrm{~m}$, Fig. 3). Indeed, skin and muscle $\delta^{15} \mathrm{~N}$ values were significantly higher in small pilot whales $(\leq 3 \mathrm{~m})$ than in larger individuals (Welch's $t$ tests, $t=3.28$ and 3.61, $p<0.001$ and $<0.01$, respectively).

$\mathrm{Hg}$ concentrations in skin and muscle were positively and linearly related, with linear models explaining 68 and $50 \%$ of $\mathrm{Hg}$ variability in 2006 and 2010, respectively (Fig. 4). Given the size-induced effect in tissue $\delta^{15} \mathrm{~N}$ values (see above), the effect of $\delta^{15} \mathrm{~N}$ values on tissue $\mathrm{Hg}$ concentrations was tested separately on mature individuals only. There was no correlation between $\mathrm{Hg}$ concentrations and $\delta^{15} \mathrm{~N}$ values in skin $\left(F 1,60=0.146, R^{2}\right.$ adj $\left.=0, p=0.704\right)$, whereas in muscle a negative relationship was highlighted $(F 1,75=19.33, p<0.001)$, but the explained variance was very low $\left(R^{2}\right.$ adj $\left.=0.19\right)$. The influence of individual traits (sex and $\mathrm{TL}$ ), year of stranding and $\delta^{13} \mathrm{C}$ values on tissue $\mathrm{Hg}$ concentrations was tested through GLMs. For skin, the most parsimonious model selected by AICc values included the effect of TL and sex in explaining $\mathrm{Hg}$ values (Table 2). Females had significantly higher skin $\mathrm{Hg}$ concentrations than males ( $4.8 \pm 2.1$ vs. $3.6 \pm 2.7 \mu \mathrm{g} \mathrm{g}^{-1} \mathrm{dw}$ ), with concentrations increasing with TL (Fig. 5). For muscle, the best fit to the $\mathrm{Hg}$ data was obtained for the maximal model, which included the effect of sex, TL, year, $\delta^{13} \mathrm{C}$ values and their interactions (Table 2). Muscle Hg concentration was significantly higher in females than in males $\left(6.0 \pm 2.8 v s .5 .1 \pm 3.1 \mu \mathrm{g} \mathrm{g}^{-1} \mathrm{dw}\right)$ and higher in 2006 than in 2010 (Table 1).

\section{Discussion}




\section{Foraging ecology and at-sea distribution}

Sightings from long-liners emphasize the regular occurrence of southern long-finned pilot whales in slope waters around the Kerguelen Archipelago (Fig. 1). These at-sea observations were highly biased towards the Patagonian toothfish fishing grounds. However, the few previous sightings again points out the importance of slope waters for pilot whales in the area, with rare observations near the Kerguelen coastline (Robineau 1989; Robineau and Duhamel 2006). These observations are in agreement with long-finned pilot whales inhabiting deep oceanic waters and zones of higher productivity along the continental and island shelf breaks, apparently venturing sometimes into neritic waters (Abend and Smith 1999).

Muscle $\delta^{13} \mathrm{C}$ and $\delta^{15} \mathrm{~N}$ values of long-finned pilot whales from Kerguelen Islands are similar to the isotopic data from Australian specimens (Davenport and Bax 2002). However, spatial variations in isotopic baselines preclude direct comparison of raw $\delta^{13} \mathrm{C}$ and $\delta^{15} \mathrm{~N}$ values of pilot whales living in different water masses (Table 3). In contrast, isotopic comparisons together with the known food and feeding ecology of air-breathing vertebrates from Kerguelen Islands helped delineating the whale foraging habitat $\left(\delta^{13} \mathrm{C}\right)$ and dietary habits $\left(\delta^{15} \mathrm{~N}\right)$. In brief, many investigations were conducted over the last 20 years on various Kerguelen seabirds (e.g. penguins, albatrosses and petrels) and pinnipeds (e.g. elephant seal and fur seals) and their prey using a variety of complementary methods (dietary analyses, bio-logging and stable isotopes) thus allowing defining relevant control species from different habitats (benthic versus pelagic, coastal versus offshore) and with different diets (crustaceans, cephalopods and fish) (Online Resource 3).

The relatively high muscle $\delta^{13} \mathrm{C}$ values of Kerguelen pilot whales preclude feeding in Antarctic waters (Cherel 2008). Instead, their muscle $\delta^{13} \mathrm{C}$ values are similar to those of the Patagonian toothfish that feed over the Kerguelen outer shelf and slope waters (Cherel et al. 2008, unpublished data). Alternatively, since inshore-offshore and latitudinal $\delta^{13} \mathrm{C}$ gradients overlap in the area (Cherel and Hobson 2007), the $\delta^{13} \mathrm{C}$ values may also suggest that pilot whales migrated from the subtropical to the subantarctic zone. However, the lack of associated high muscle $\delta^{15} \mathrm{~N}$ values resulting from high $\delta^{15} \mathrm{~N}$ baseline level in the subtropics (Altabet and François 1994; Lourey et al. 2003) does not support the migration hypothesis. Hence, the most parsimonious explanation of their muscle $\delta^{13} \mathrm{C}$ values is that southern long-finned pilot whales foraged primarily over the Kerguelen shelf break and nearby subantarctic oceanic waters in the months preceding their stranding, which is in agreement with at-sea observations of the species (see above). 
Muscle $\delta^{15} \mathrm{~N}$ value of pilot whales was much higher than that of crustacean-eaters from Kerguelen Islands, namely the southern rockhopper penguin and Antarctic and thin-billed prions (Cherel et al. 2010, Online Resource 3). The whale $\delta^{15} \mathrm{~N}$ value was $1 \%$ above that of the myctophid fish consumers king penguin and Antarctic fur seal and $1 \%$ below the $\delta^{15} \mathrm{~N}$ value of black-browed albatross, which has a catholic diet including large fish and squid (Cherel et al. 2000b, 2008, 2010). Accordingly, pilot whale muscle $\mathrm{Hg}$ concentration was two and one order of magnitude higher than those of planktivorous petrels and of the crustacean- and myctophid-eater blue petrel, respectively (Bocher et al. 2003). Furthermore, the pilot whale $\mathrm{Hg}$ concentration was two times higher than that of the white-chinned petrel, which has a more diverse diet, including various fish and squid species (Delord et al. 2010; Cipro et al. 2014). Hence, both trophic markers $\left(\delta^{15} \mathrm{~N}\right.$ and $\left.\mathrm{Hg}\right)$ indicate that pilot whales did not prey primarily upon crustaceans, but favoured a mixed diet of fish and squid in Kerguelen waters. While prey cannot be determined at the species level using $\delta^{15} \mathrm{~N}$ values, feeding on a large spectrum of fish and squid is in general agreement with stomach content analysis of long-finned pilot whales elsewhere (Desportes and Mouritsen 1993; Pauly et al. 1998; Spitz et al. 2011). The trophic position of the long-finned pilot whale within the Kerguelen oceanic ecosystem can be estimated at 4.7 , using the combination of the mean whale muscle $\delta^{15} \mathrm{~N}$ value, an assumed trophic level of 2.0 for the herbivorous salp Salpa thompsoni with a $3.4 \% \delta^{15} \mathrm{~N}$ value (Cherel et al. 2008), and a $2.7 \%{ }^{15} \mathrm{~N}$ enrichment factor between prey and cetacean muscle (Borrell et al. 2012). The trophic position compares well with those previously estimated for the northern subspecies using muscle isotopic measurements (4.9), standardized diet composition (4.4) and ecosystem modelling (4.7) (Pauly et al. 1998; Lassalle et al. 2014). In Kerguelen waters, the southern long-finned pilot whale is a top consumer close to other marine mammals (e.g. southern elephant seal, 4.6) and large fish (e.g. Patagonian toothfish, 5.0), but the albatross trophic position is higher (5.3-5.7) and the oceanic ecosystem is dominated by the colossal squid (6.1; Cherel et al. 2008).

Tissue-related isotopic differences result from two nonexclusive explanations, namely different biochemical compositions leading to tissue-specific isotopic discrimination factors, and tissuespecific isotopic turn-over rates inducing different trophic temporal integrations (Wolf et al. 2009). Little or no differences were found in the isotopic ratios of lipid-extracted skin and muscle of cetaceans and hence in their discrimination factors (Borrell et al. 2012; HorstmannDehn et al. 2012). Consequently, the consistent $\sim 0.7 \%$ o $\delta^{13} \mathrm{C}$ difference between the two tissues of southern long-finned pilot whales suggests a temporal shift associated with a spatial change in the main foraging habitat, since skin and muscle integrate periods of weeks and months, 
respectively (Newsome et al. 2010; Browning et al. 2014). However, isotopic variability of Kerguelen southern long-finned pilot whales overall remained low $(<1 \%$, Table 1$)$ within and between tissues and when compared the two stranding events. Such a low degree of isotopic variability suggests no major changes in the whale feeding ecology in Kerguelen waters over the medium- and long-term (skin versus muscle, and 2006 versus 2010, respectively). Interestingly, most small individuals presented higher skin and muscle $\delta^{15} \mathrm{~N}$ values than larger pilot whales. An ontogenetic isotopic shift associated with nursing and weaning was previously described in pinnipeds and cetaceans, which can be explained by the consumption of milk by calves and the resulting higher trophic position $\left(\delta^{15} \mathrm{~N}\right)$ of the young relative to its mother (Ducatez et al. 2008; Newsome et al. 2009). In pilot whales, juveniles are weaned during a protracted period during which they progressively increase their consumption of natural prey (Desportes and Mouritsen 1993), thus inducing a concomitant $\delta^{15} \mathrm{~N}$ decrease down to adult values. Neither tissue $\delta^{13} \mathrm{C}$ nor $\delta^{15} \mathrm{~N}$ values changed with size thereafter, suggesting no major foraging variations associated with growth and age after weaning in Kerguelen pilot whales (Fig. 3).

\section{Hg exposure}

Exposure to $\mathrm{Hg}$ was previously investigated in many species of marine mammals, with liver exhibiting consistently the highest $\mathrm{Hg}$ concentrations, followed by kidney, muscle and skin (Thompson 1990; Das et al. 2003). Accordingly, long-finned pilot whales presented relatively low and almost similar Hg levels in muscle and skin samples (Frodello et al. 2000, this study). Cetacean skin is a fragile and highly vascularised surface tissue in which $\mathrm{Hg}$ is first sequestered into keratin and then eliminated by epidermal sloughing (Wagemann and Kozlowska 2005). Despite $\mathrm{Hg}$ excretion by desquamation, positive correlations had been reported between $\mathrm{Hg}$ levels in skin and internal organs like liver (e.g. Dall's porpoises and small delphinids in Yang et al. 2002 and Aubail et al. 2013, respectively). The equation between $\mathrm{Hg}$ levels in skin and liver of delphinids (Aubail et al. 2013) allows calculating an estimated mean value and range of $494 \pm 490(0.3-2,210) \mu \mathrm{g} \mathrm{g}^{-1} \mathrm{dw}$ in the liver of southern long-finned pilot whales from Kerguelen Islands. Within that context, the present study showed for the first time significant positive correlation between skin and muscle $\mathrm{Hg}$ values in cetaceans (Fig. 4). Hence, skin biopsy may be used as a non-destructive tool for assessing $\mathrm{Hg}$ concentrations of free-ranging pilot whales and for predicting their $\mathrm{Hg}$ concentrations in liver and muscle that are the two main $\mathrm{Hg}$ body reservoirs in marine mammals (Yamamoto et al. 1987). 
$\mathrm{Hg}$ burden was not previously investigated in the southern long-finned pilot whale but was determined in the northern subspecies and in the congeneric short-finned pilot whale (Globicephala macrorhynchus) that lives in warmer waters. Muscle $\mathrm{Hg}$ concentration of pilot whales from Kerguelen Islands was close to the levels measured in populations inhabiting the Faroe Islands and northern Japan. It was 2.5 times lower than $\mathrm{Hg}$ level in specimens from the Lesser Antilles and 4.4-7.8 times lower than $\mathrm{Hg}$ concentrations in animals living in the Mediterranean Sea (Corsica), southern Japan and New Caledonia (Table 3). Local biogeochemistry, geology and anthropogenic activities indirectly affect $\mathrm{Hg}$ content of cetaceans through $\mathrm{Hg}$ concentrations of their prey. For example, pelagic organisms are naturally $\mathrm{Hg}$ enriched in the Mediterranean Sea due to high organic $\mathrm{Hg}$ availability, and consequently Mediterranean predators, including cetaceans, contain high $\mathrm{Hg}$ levels (Cossa and Coquery 2005; Savery et al. 2013). Conversely, the comparatively low $\mathrm{Hg}$ burden of Kerguelen pilot whales can be explained by the combination of low organic $\mathrm{Hg}$ availability in subantarctic waters (Cossa et al. 2011) together with the absence of human activities releasing $\mathrm{Hg}$ in the area. Within odontocetes, the Kerguelen long-finned pilot whale was less contaminated or their muscle $\mathrm{Hg}$ concentrations were within the same range of values than most species so far investigated, but their muscle $\mathrm{Hg}$ level was consistently higher than that of mysticetes (Thompson 1990; Endo et al. 2003, 2004, 2012). These taxa-related differences can be explained by different feeding habits, with baleen whales generally preying upon lower trophic level prey than toothed whales, i.e. crustaceans and small fish versus squid and larger fish, respectively.

Significant variations in $\mathrm{Hg}$ burdens occurred between the two mass-stranding events. Muscle $\mathrm{Hg}$ concentration was three times lower in 2010 than in 2006, with no corresponding change in skin values. These inter-annual differences are difficult to interpret, but they might result from differential $\mathrm{Hg}$ turnover rates between skin and muscle that remain to be determined. Tissue $\mathrm{Hg}$ concentrations were positively correlated to individual TL in southern long-finned pilot whales, which is consistent with previous findings on cetaceans (Honda et al. 1983; Thompson 1990; Leonzio et al. 1992). Since tissue $\delta^{15} \mathrm{~N}$ values did not increase with TL, the size-related $\mathrm{Hg}$ change was not a consequence of a progressive dietary shift and there was therefore a decoupling between $\mathrm{Hg}$ concentrations and trophic position. Compared to males, female pilot whales grow more slowly, are smaller (mean adult lengths 4.5 versus $5.7 \mathrm{~m}$ ) and live longer (up to 59 and 46 years, respectively) (Bloch et al. 1993b). Hence, for a given body size, females are older than males and, accordingly, more $\mathrm{Hg}$ contaminated (Fig. 5). Overall, skin and muscle 
$\mathrm{Hg}$ concentrations were also higher in females, which is in agreement with higher liver $\mathrm{Hg}$ levels in females than in males of the northern subspecies (Caurant et al. 1993).

In conclusion, both ecological tracers $\left(\delta^{13} \mathrm{C}, \delta^{15} \mathrm{~N}, \mathrm{Hg}\right)$ and at-sea observations indicate that Kerguelen southern long-finned pilot whales foraged primarily in slope waters and oceanic subantarctic waters where they occupy a high trophic position. Their precise feeding habits remain to be determined, but it is likely that they prey on a mixed diet of fish and squid in the deep sea, as other populations of pilot whales do (Aguilar de Soto et al. 2008; Spitz et al. 2011). Muscle $\mathrm{Hg}$ concentration of southern long-finned pilot whales is close to or lower than that of many odontocete species. Noticeably, they are less $\mathrm{Hg}$ contaminated than most pilot whale populations studied so far, thus suggesting that the southern subspecies is not at a high risk to $\mathrm{Hg}$-induced damages in the remote islands of the Southern Ocean.

Acknowledgements: The authors thank Y. Charbonnier, A. Chevallier, J. Nezan and other fieldworkers who collected tissue samples in the field, G. Guillou for stable isotope analysis, and C. Churlaud and M. Brault-Favrou for their assistances during $\mathrm{Hg}$ analysis. We are grateful to the fishery observers on longliners, COPEC Service of Territoire des Terres Australes et Antarctiques Françaises (TAAF). The present work was supported financially and logistically by the Agence Nationale de la Recherche Programme TOPP-PATCHES (F. Bailleul), the Institut Polaire Français Paul Emile Victor (IPEV, Programme No. 109, H. Weimerskirch), and the TAAF.

\section{References}

Abend AG, Smith TD (1995) Differences in ratios of stable isotopes of nitrogen in long-finned pilot whales (Globicepha melas) in the western and eastern North Atlantic. ICES J Mar Sci 52:837-841

Abend AG, Smith TD (1997) Differences in stable isotope ratios of carbon and nitrogen between long-finned pilot whales (Globicepha melas) and their primary prey in the western north Atlantic. ICES J Mar Sci 54:500503

Abend AG, Smith TD (1999) Review of distribution of the long-finned pilot whale (Globicephala melas) in the North Atlantic and Mediterranean. NOAA Tech Memo NMFS-NE 117

Aguilar de Soto N, Johnson MP, Madsen PT, Diaz F, Dominguez I, Brito A, Tyack P (2008) Cheetahs of the deep sea: deep foraging sprints in short-finned pilot whales off Tenerife (Canary Islands). J Anim Ecol 77:936947

Akaïke H (1973) Information theory and an extension of the maximum likelihood principle. In: Petrov BN, Csaki F (ed) Proceedings of the $2^{\text {nd }}$ international symposium on information theory, Akademiai Kiado, Budapest, pp 267-281

Altabet MA, François R (1994) Sedimentary nitrogen isotopic ratio as a recorder for surface ocean nitrate utilization. Glob Biogeochem Cycles 8:103-116

Arima S, Nagakura K (1979) Mercury and selenium content of Odontoceti. Nippon Suisan Gakkaishi (Bull Jpn Soc Sci Fish) 45:623-626

Aubail A, Mendez-Fernandez P, Bustamante P, Churlaud C, Ferreira M, Vingada JV, Caurant F (2013) Use of 
skin and blubber tissues of small cetaceans to assess the trace element content of internal organs. Mar Pollut Bull 76:158-169

Beatson EL, O’Shea S (2009) Stomach contents of long-finned pilot whales, Globicephala melas, mass-stranded on Farewell Spit, Golden Bay in 2005 and 2008. N Z J Zool 36:47-58

Beatson E, O'Shea S, Ogle M (2007a) First report on the stomach contents of long-finned pilot whales, Globicephala melas, stranded in New Zealand. N Z J Zool 34:51-56

Beatson E, O’Shea S, Stone C, Shortland T (2007b) Notes on New Zealand mammals 6. Second report on the stomach contents of long-finned pilot whales, Globicephala melas. N Z J Zool 34:359-362

Blévin P, Carravieri A, Jaeger A, Chastel O, Bustamante P, Cherel Y (2013) Wide range of mercury contamination in chicks of Southern Ocean seabirds PloS one 8(1): e54508. doi: 10.1371/journal.pone.0054508

Bloch D, Desportes G, Mouritsen R, Skaaning S, Stefanson E (1993a) An introduction to studies of the ecology and status of the long-finned pilot whale (Globicephala melas) off the Faroe Islands, 1986-1988. Rep Int Whal Comm Spec Issue 14:1-32

Bloch D, Lockyer C, Zachariassen M (1993b) Age and growth parameters of the long-finned pilot whale off the Faroe Islands. Rep Int Whal Comm Spec Issue 14:163-207

Bocher P, Caurant F, Miramand P, Cherel Y, Bustamante P (2003) Influence of the diet on the bioaccumulation of heavy metals in zooplankton-eating petrels at Kerguelen archipelago, Southern Indian Ocean. Polar Biol 26:759-767

Borrell A, Abad-Oliva N, Gomez-Campos E, Gimenez J, Aguilar A (2012) Discrimination of stable isotopes in fin whale tissues and application to diet assessment in cetaceans. Rapid Commun Mass Spectrom 26:15961602

Bowen WD (1997) Role of marine mammals in aquatic ecosystems. Mar Ecol Prog Ser 158:267-274

Browning NE, Dold C, I-Fan J, Worthy GAJ (2014) Isotope turnover rates and diet-tissue discrimination in skin of ex situ bottlenose dolphins (Tursiops truncatus). J Exp Biol 217:214-221

Burnham KP, Anderson DR (2002) Model selection and multimodel inference: a practical information-theoretic approach, $2^{\text {nd }}$ ed. Springer, New York.

Bustamante P, Garrigue C, Breau L, Caurant F, Dabin W, Greaves J, Dodemont RÇ (2003) Trace elements in two odontocete species (Kogia breviceps and Globicephala macrorhynchus) stranded in New Caledonia (South Pacific). Environ Pollut 124: 263-271

Bustamante P, Lahaye V, Durnez C, Churlaud C, Caurant F (2006) Total and organic Hg concentrations in cephalopods from the North Eastern Atlantic waters: influence of geographical origin and feeding ecology. Sci Total Environ 368:585-596

Carravieri A, Bustamante P, Churlaud C, Cherel Y (2013) Penguins as bioindicators of mercury contamination in the Southern Ocean: birds from the Kerguelen Islands as a case study. Sci Total Environ 454-455:141-148

Carravieri A, Cherel Y, Blévin P, Chastel O, Brault-Favrou M, Chastel O, Bustamante P (2014) Mercury exposure in a large subantarctic avian community. Environ Pollut 190:51-57

Caurant F, Amiard-Triquet C, Amiard JC (1993) Factors influencing the accumulation of metals in pilot whales (Globicephala melas) off the Faroe Islands. Rep Int Whal Comm Spec Issue 14:369-390

Caurant F, Navarro M, Amiard JC (1996) Mercury in pilot whales: possible limits to the detoxification process. Sci Total Environ 186:95-104 
Cherel Y (2008) Isotopic niches of emperor and Adélie penguins in Adélie Land, Antarctica. Mar Biol 154:813821

Cherel Y, Hobson KA (2007) Geographical variation in carbon stable isotope signatures of marine predators: a tool to investigate their foraging areas in the Southern Ocean. Mar Ecol Prog Ser 329:281-287

Cherel Y, Hobson KA, Weimerskirch H (2000a) Using stable-isotope analysis of feathers to distinguish moulting and breeding origins of seabirds. Oecologia 122:155-162

Cherel Y, Weimerskirch H, Trouvé C (2000b) Food and feeding ecology of the neritic-slope forager black-browed albatross and its relationships with commercial fisheries in Kerguelen waters. Mar Ecol Prog Ser 207:183199

Cherel Y, Ducatez S, Fontaine C, Richard P, Guinet C (2008) Stable isotopes reveal the trophic position and mesopelagic fish diet of female southern elephant seals breeding on the Kerguelen Islands. Mar Ecol Prog Ser 370:239-247

Cherel Y, Fontaine C, Richard P, Labat JP (2010) Isotopic niches and trophic levels of myctophid fishes and their predators in the Southern Ocean. Limnol Oceanogr 55:324-332

Chouvelon T, Spitz J, Cherel Y, Caurant F, Sirmel R, Mendez-Fernandez P, Bustamante P (2011) Inter-specific and ontogenic differences in $\delta^{13} \mathrm{C}$ and $\delta^{15} \mathrm{~N}$ values and $\mathrm{Hg}$ and $\mathrm{Cd}$ concentrations in cephalopods. Mar Ecol Prog Ser 433:107-120

Cipro CVZ, Cherel Y, Caurant F, Miramand P, Mendez-Fernandez P, Bustamante P (2014) Trace elements in tissues of white-chinned petrels (Procellaria aequinoctialis) from Kerguelen waters, Southern Indian Ocean. Polar Biol 37:763-771

Clarke M, Goodall N (1994) Cephalopods in the diets of three odontocete cetacean species stranded at Tierra del Fuego, Globicephala melaena (Traill, 1809), Hyperoodon planifrons Flower, 1882 and Cephalorhynchus commersonii (Lacepede, 1804). Antarct Sci 6:149-154

Cossa D, Coquery M (2005) The Mediterranean mercury anomaly, a geochemical or a biological issue. Hdb Environ Chem 5:177-208

Cossa D, Heimbürger LE, Lannuzel D, Rintoul SR, Butler ECV, Bowie AR, Averty B, Watson RJ, Remenyi T (2011) Mercury in the Southern Ocean. Geochim Cosmochim Acta 75:4037-4052

Dalerum F, Angerbjörn A (2005) Resolving temporal variation in vertebrate diets using naturally occurring stable isotopes. Oecologia 144:647-658

Dam M, Bloch D (2000) Screening of mercury and persistent organochlorine pollutants in long-finned pilot whale (Globicephala melas) in the Faroe Islands. Mar Pollut Bull 40:1090-1099

Das K, Debacker V, Pillet S, Bouquegneau JM (2003) Heavy metals in marine mammals. In: Vos JV, Bossart GD, Fournier M, O’Shea T (eds) Toxicology of marine mammals. Taylor and Francis, Washington, DC, pp 117

Das K, Holsbeek L, Browning J, Siebert U, Birkun A, Bouquegneau JM (2004) Trace metal and stable isotope measurements $\left(\delta^{13} \mathrm{C}\right.$ and $\left.\delta^{15} \mathrm{~N}\right)$ in the harbour porpoise Phocoena phocoena relicta from the Black Sea. Environ Pollut 131: 197-204

Davenport SR, Bax NJ (2002) A trophic study of a marine ecosystem off southeastern Australia using stable isotopes of carbon and nitrogen. Can J Fish Aquat Sci 59:514-530

de Stephanis R, Garcia-Tiscar S, Verborgh P, Esteban-Pavo R, Pérez S, Minvielle-Sebastia L, Guinet C (2008) 
Diet of the social groups of long-finned pilot whales (Globicephala melas) in the Strait of Gibraltar. Mar Biol 154:603-612

Delord K, Cotté C, Péron C, Marteau C, Pruvost P, Gasco N, Duhamel G, Cherel Y, Weimerskirch H (2010) Atsea distribution and diet of an endangered top predator: relationship between white-chinned petrels and commercial longline fisheries. Endanger Species Res 13:1-16

De Niro MJ, Epstein S (1977) Mechanism of carbon isotope fractionation associated with lipid synthesis. Science 197:261-263

Desportes G, Mouritsen R (1993) Preliminary results on the diet of long-finned pilot whales off the Faroe Islands. Rep Int Whal Comm Spec Issue 14:305-324

Donovan GP, Lockyer CH, Martin AR (1993) Biology of the Northern Hemisphere pilot whales. A collection of papers. Rep Int Whal Comm Spec Issue 14:1-479

dos Santos RA, Haimovici M (2001) Cephalopods in the diet of marine mammals stranded or incidentally caught along southeastern and southern Brazil $\left(21-34^{\circ} \mathrm{S}\right)$. Fish Res 52:99-112

Ducatez S, Dalloyau S, Richard P, Guinet C, Cherel Y (2008) Stable isotopes document winter trophic ecology and maternal investment of adult female southern elephant seals (Mirounga leonina) breeding at the Kerguelen Islands. Mar Biol 155:413-420

Endo T, Hotta Y, Haraguchi K, Sakata M (2003) Mercury contamination in the red meat of whales and dolphins marketed for human consumption in Japan. Environ Sci Technol 37:2681-2685

Endo T, Haraguchi K, Cipriani F, Simmonds MP, Hotta Y, Sakata M (2004) Contamination by mercury and cadmium in the cetacean products from Japanese market. Chemosphere 54:1653-1662

Endo T, Haraguchi K, Hotta Y, Hisamichi Y, Lavery S, Dalebout ML, Baker CS (2005) Total mercury, methyl mercury, and selenium levels in the red meat of small cetaceans sold for human consumption in Japan. Environ Sci Technol 39:5703-5708

Endo T, Hisamichi Y, Kimura O, Haraguchi K, Lavery S, Dalebout ML, Funahashi N, Baker CS (2010) Stable isotope ratios of carbon and nitrogen and mercury concentrations in 13 toothed whale species taken from the western Pacific Ocean off Japan. Environ Sci Technol 44:2675-2681

Endo T, Hotta Y, Hisamichi Y, Kimura O, Sato R, Haraguchi K, Funahashi N, Baker CS (2012) Stable isotope ratios and mercury levels in red meat products from baleen whales sold in Japanese markets. Ecotoxicol Environ Saf 79:35-41

Fitzgerald WF, Engstrom DR, Mason RP, Nater EA (1998) The case for atmospheric mercury contamination in remote areas. Environ Sci Technol 32:1-7

Fitzgerald WF, Lamborg CH, Hammerschmidt CR (2007) Marine biogeochemical cycling of mercury. Chem Rev 107:641-662.

Frodello JP, Roméo M, Viale D (2000) Distribution of mercury in the organs and tissues of five toothed-whale species of the Mediterranean. Environ Pollut 108: 447-452

Gales R, Pemberton D, Clarke M, Lu CC (1992) Stomach contents of long-finned pilot whales (Globicephala melas) and bottlenose dolphins (Tursiops truncatus) in Tasmania. Mar Mammal Sci 8: 405-413

Gaskin DE, Smith GJD, Arnold PW, Louisy MV, Frank R, Holdrinet M, McWade JW (1974) Mercury, DDT, dieldrin, and PCB in two species of Odontoceti (Cetacea) from St. Lucia, Lesser Antilles. J Fish Res Board Can 31:1235-1239 
Goodall RNP, Galeazzi AR (1985) A review of the food habits of the small cetaceans of the Antarctic and sub-

Antarctic. In: Siegfried WR, Condy PR, Laws RM (eds) Antarctic nutrient cycles and food webs. Springer, Berlin, pp 566-572

Gray JS (2002) Biomagnification in marine systems: the perspective of an ecologist. Mar Pollut Bull 45:46-52

Hobson KA, Piatt JF, Pitocchelli J (1994) Using stable isotopes to determine seabird trophic relationships. J Anim Ecol 63:786-798

Honda K, Tatsukawa R, Itano K, Miyazaki N, Fujiyama T (1983) Heavy metal concentrations in muscle, liver and kidney tissue of striped dolphin, Stenella coeruleoalba, and their variations with body length, weight, age and sex. Agric Biol Chem 47:1219-1228

Horstmann-Dehn L, Follmann EH, Rosa C, Zelensky G, George C (2012) Stable carbon and nitrogen isotope ratios in muscle and epidermis of arctic whales. Mar Mammal Sci 28:E173-E190

Jaeger A, Lecomte VJ, Weimerskirch H, Richard P, Cherel Y (2010) Seabird satellite tracking validates the use of latitudinal isoscapes to depict predators' foraging areas in the Southern Ocean. Rapid Commun Mass Spectrom 24:3456-3460

Julshamn K, Andersen A, Ringdal O, Morkore J (1987) Trace elements intake in the Faroe Islands I. Element levels in edible parts of pilot whales (Globicephalus meleanus). Sci Total Environ 65:53-62

Kelly JF (2000) Stable isotopes of carbon and nitrogen in the study of avian and mammalian trophic ecology. Can J Zool 78:1-27

Kiszka J, Oremus M, Richard P, Poole M, Ridoux V (2010) The use of stable isotope analyses from skin biopsy samples to assess trophic relationships of sympatric delphinids off Moorea (French Polynesia). J Exp Mar Biol Ecol 395:48-54

Lahaye V, Bustamante P, Dabin W, Van Canneyt O, Dhermain F, Cesarini C, Pierce GJ, Caurant F (2006) New insights from age determination on toxic element accumulation in striped and bottlenose dolphins from Atlantic and Mediterranean waters. Mar Pollut Bull 52:1219-1230

Lassalle G, Chouvelon T, Bustamante P, Niquil N (2014) An assessment of the trophic structure of the Bay of Biscay continental shelf food web: comparing estimates derived from an ecosystem model and isotopic data. Prog Oceanogr 120:205-215

Lebreton JD, Burnham KP, Clobert J, Anderson DR (1992) Modeling survival and testing biological hypotheses using marked animals: a unified approach with case studies. Ecol Monogr 62:67-118

Leonzio C, Focardi S, Fossi C (1992) Heavy metals and selenium in stranded dolphins of the Northern Tyrrhenian (NW Mediterranean). Sci Tot Environ 119: 77-84

Lourey MJ, Trull TW, Sigman DM (2003) Sensitivity of $\delta^{15} \mathrm{~N}$ of nitrate, surface suspended and deep sinking particulate nitrogen to seasonal nitrate depletion in the Southern Ocean. Glob Biogeochem Cycles 17:1081

Mansilla L, Olavarra C, Vega MA Stomach contents of long-finned pilot whales (Globicephala melas) from southern Chile. Pol Biol 35: 1929-1933

Martin A, Pruvost P (2007) Pecheker, relational database for analysis and management of fisheries and related biological data from the French southern ocean fisheries monitoring scientific programs, Muséum National d' Histoire Naturelle.

McCutchan JH, Lewis WM, Kendall C, McGrath CC (2003) Variation in trophic shift for stable isotope ratios of carbon, nitrogen, and sulfur. Oikos 102:378-390 
Mendez-Fernandez P, Bustamante P, Bode A, Chouvelon T, Ferreira M, Lopez A, Pierce GJ, Santos MB, Spitz J, Vingada JV, Caurant F (2012) Foraging ecology of five toothed whale species in the Northwest Iberian Peninsula, inferred using carbon and nitrogen isotope ratios. J Exp Mar Biol Ecol 413:150-158

Mendez-Fernandez P, Pierce GJ, Bustamante P, Chouvelon T, Ferreira M, Gonzalez AF, Lopez A, Read FL, Santos MB, Spitz J, Vingada JV, Caurant F (2013) Ecological niche segregation among five toothed whale species off the NW Iberian Peninsula using ecological tracers as multi-approach. Mar Biol 160:2825-2840

Newsome SD, Etnier MA, Monson DH, Fogel ML (2009) Retrospective characterization of ontogenetic shifts in killer whale diets via $\delta^{13} \mathrm{C}$ and $\delta^{15} \mathrm{~N}$ analysis of teeth. Mar Ecol Prog Ser 374:229-242

Newsome SD, Clementz MT, Koch PL (2010) Using stable isotope biogeochemistry to study marine mammal ecology. Mar Mammal Sci 26:509-572

Nino-Torres CA, Gallo-Reynoso JP, Galvan-Magana F, Escobar-Briones E, Macko SA (2006) Isotopic analysis of $\delta^{13} \mathrm{C}, \delta^{15} \mathrm{~N}$, and $\delta^{34} \mathrm{~S}$ “A feeding tale" in teeth of the long-beaked common dolphin, Delphinus capensis. Mar Mammal Sci 22:831-846

Olson PA (2009) Pilot whales Globicephala melas and G. macrorhynchus. In: Perrin WF, Würsig B, Thewissen JGM (eds) Encyclopedia of marine mammals, 2nd edn. Academic Press, San Diego, pp 847-852

Oremus M, Gales R, Dalebout ML, Funahashi N, Endo T, Kage T, Steel D, Baker SC (2009) Worldwide mitochondrial DNA diversity and phylogeography of pilot whales (Globicephala spp.). Biol J Linnean Soc 98:729-744

Pajuelo M, Bjorndal KA, Reich KJ, Arendt MD, Bolten AB (2012) Distribution of foraging habitats of male loggerhead turtles (Caretta caretta) as revealed by stable isotopes and satellite telemetry. Mar Biol 159:12551267

Park YH, Gambéroni L (1997) Cross-frontal exchange of Antarctic intermediate water and Antarctic bottom water in the Crozet Basin. Deep Sea Res II 44:963-986

Pauly D, Trites AW, Capuli E, Christensen V (1998) Diet composition and trophic levels of marine mammals. ICES J Mar Sci 55:467-481

Praca E, Laran S, Lepoint G, Thomé JP, Quetglas A, Belcari P, Sartor P, Dhermain F, Ody D, Tapie N, Budzinski H, Das K (2011) Toothed whales in the northwestern Mediterranean: insight into their feeding ecology using chemical tracers. Mar Pollut Bull 62:1058-1065

R Development Core Team (2013) R: a language and environment for statistical computing. R Foundation for Statistical Computing, Vienna, Austria

Ramos R, Gonzalez-Solis J (2012) Trace me if you can: the use of intrinsic biogeochemical markers in marine top predators. Front Ecol Environ 10:258-266

Robineau D (1989) Les cétacés des îles Kerguelen. Mammalia 53:265-278

Robineau D, Duhamel G (2006) Nouvelles données sur les cétacés des îles Kerguelen. Mammalia 70:28-39

Rosel PE (2003) PCR-based sex determination in odontocete cetaceans. Conserv Genet 4:647-649

Santos MB, Clarke MR, Pierce GJ (2001) Assessing the importance of cephalopods in the diets of marine mammals and other top predators: problems and solutions. Fish Res 52:121-139

Savery LC, Evers DC, Wise SS, Falank C, Wise J, Gianios C, Kerr I, Payne R, Thompson WD, Perkins C, Zheng T, Zhu C, Benedict L, Wise JP (2013) Global mercury and selenium concentrations in skin from free-ranging sperm whales (Physeter macrocephalus). Sci Total Environ 450-451:59-71 
Shaw CN, Wilson PJ, White BN (2003) A reliable molecular method of gender determination for mammals. J Mammal 84:123-128

Spitz J, Cherel Y, Bertin S, Kiszka J, Dewez A, Ridoux V (2011) Prey preferences among the community of deepdiving odontocetes from the Bay of Biscay, Northeast Atlantic. Deep Sea Res I 58:273-282

Thompson DR (1990) Metal levels in marine vertebrates. In: Furness RW, Rainbow PS (eds) Heavy metals in the marine environment. CRC Press, Boca Raton, pp 143-182

Vanderklift A, Ponsard S (2003) Sources of variation in consumer-diet $\delta^{15} \mathrm{~N}$ enrichments: a meta-analysis. Oecologia 136:169-182

Wagemann R, Kozlowska H (2005) Mercury distribution in the skin of beluga (Delphinapterus leucas) and narwhal (Monodon monoceros) from the Canadian Arctic and mercury burdens and excretion by moulting. Sci Total Environ 351-352:333-343

Wolf N, Carleton SA, Martinez del Rio C (2009) Ten years of experimental animal isotopic ecology. Funct Ecol 23:17-26

Yamamoto Y, Honda K, Hidaka H, Tatsukawa R (1987) Tissue distribution of heavy metals in Weddell Seals (Leptonychotes weddellii). Mar Pollut Bull 18:164-169

Yang J, Kunito T, Tanabe S, Amano M, Miyazaki N (2002) Trace elements in skin of Dall's porpoises (Phocoenoides dalli) from the northern waters of Japan: an evaluation for utilization as non-lethal tracers. Mar Pollut Bull 45: 230-236 


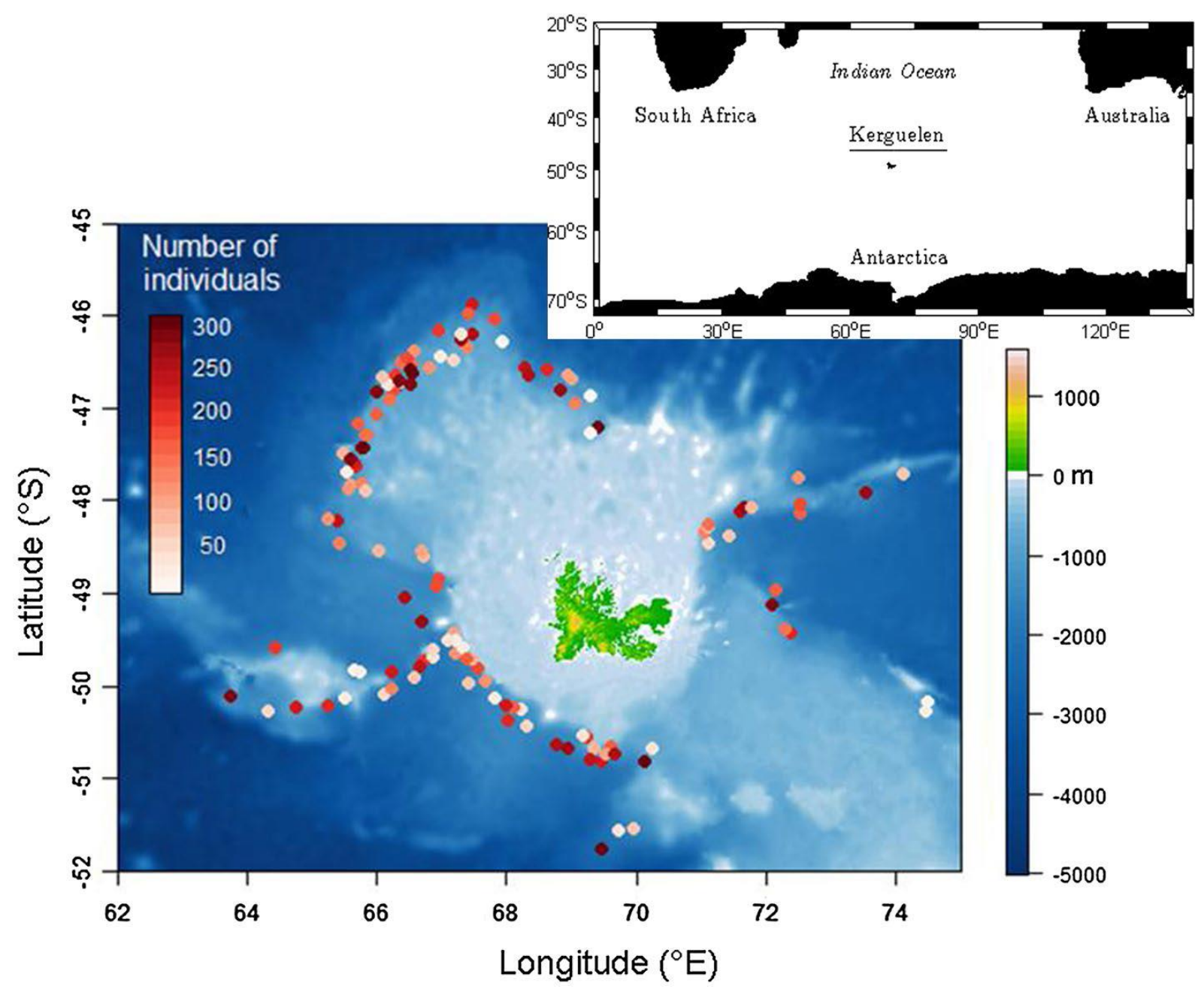

Figure 1. Location of Kerguelen Islands within the Indian Ocean (inset) and spatial at-sea observations of long-finned pilot whales from long-liners targeting Patagonian toothfish in Kerguelen waters during the period 2003-2012. Colour scale on the right indicates bathymetry (m) 


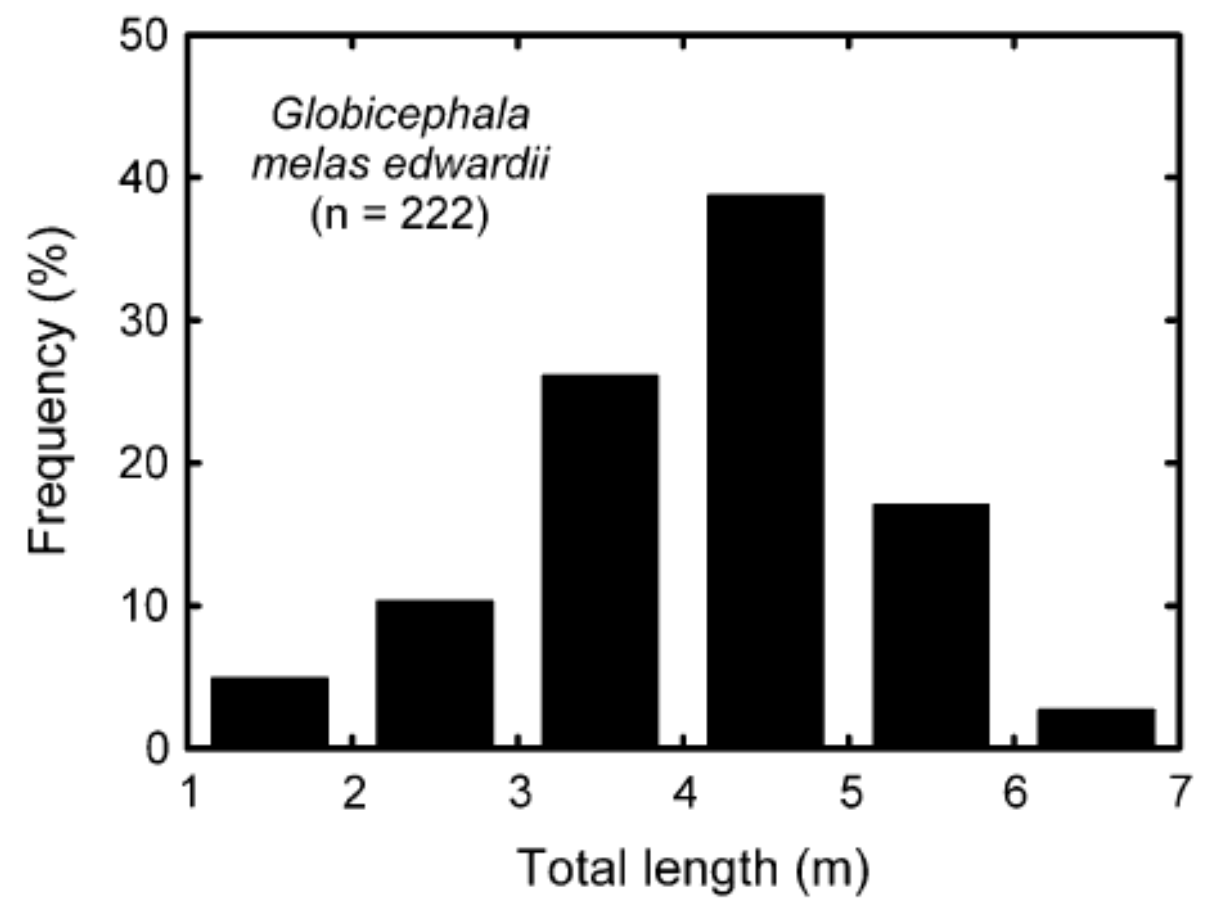

Figure 2. Frequency distribution of total length of stranded long-finned pilot whales from Kerguelen Islands (pooled data from the two mass stranding events) 

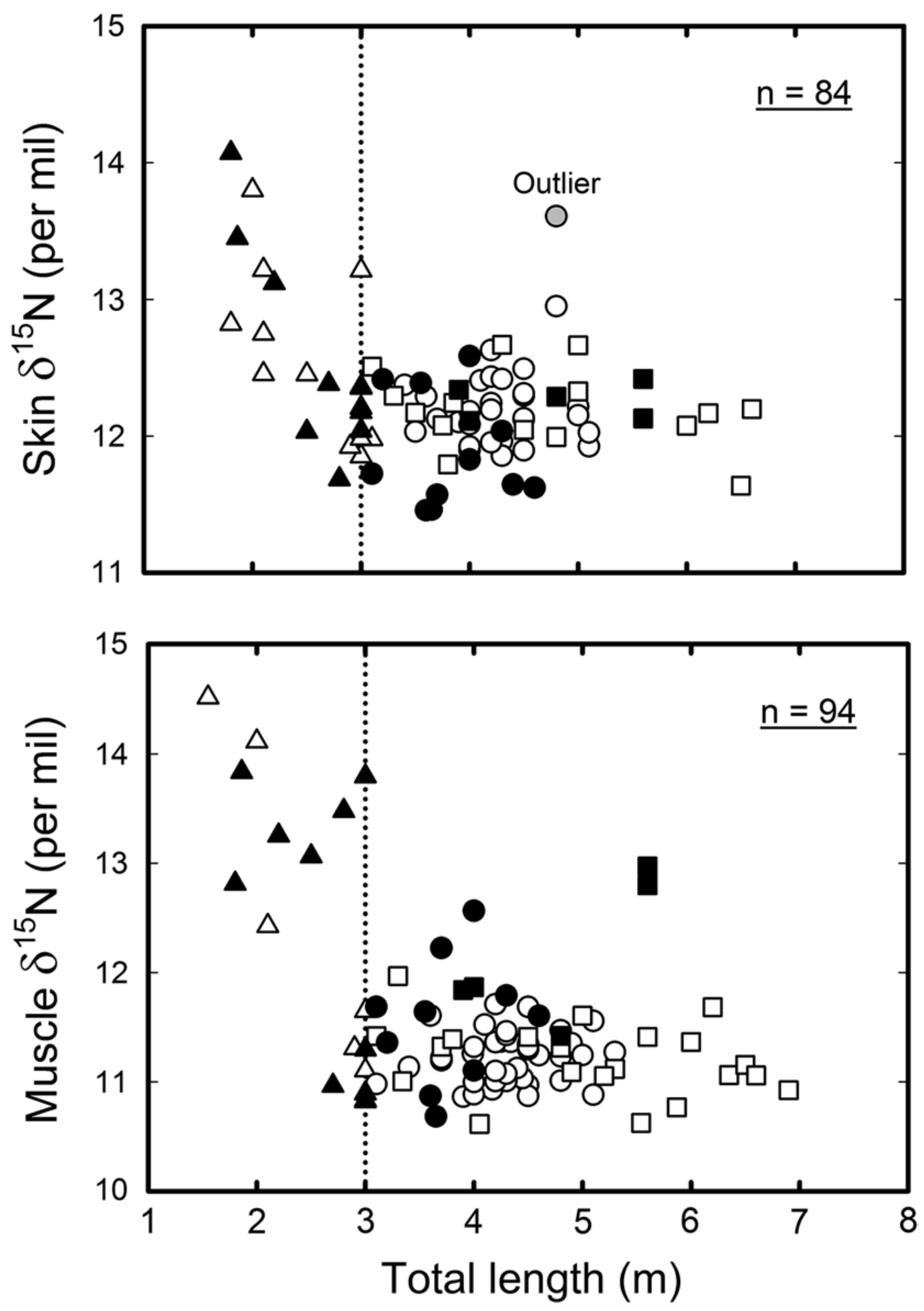

Figure 3. Tissue $\delta^{15} \mathrm{~N}$ values versus total length of calves (triangles), females (circles) and males (squares) long-finned pilot whales that stranded in 2006 (white) and 2010 (black). Dotted lines refer to the length at weaning $(3 \mathrm{~m})$ and outlier depicts an individual with both high $\delta^{13} \mathrm{C}$ and $\delta^{15} \mathrm{~N}$ values suggesting that it migrated from warmer northern waters to the Kerguelen Islands 


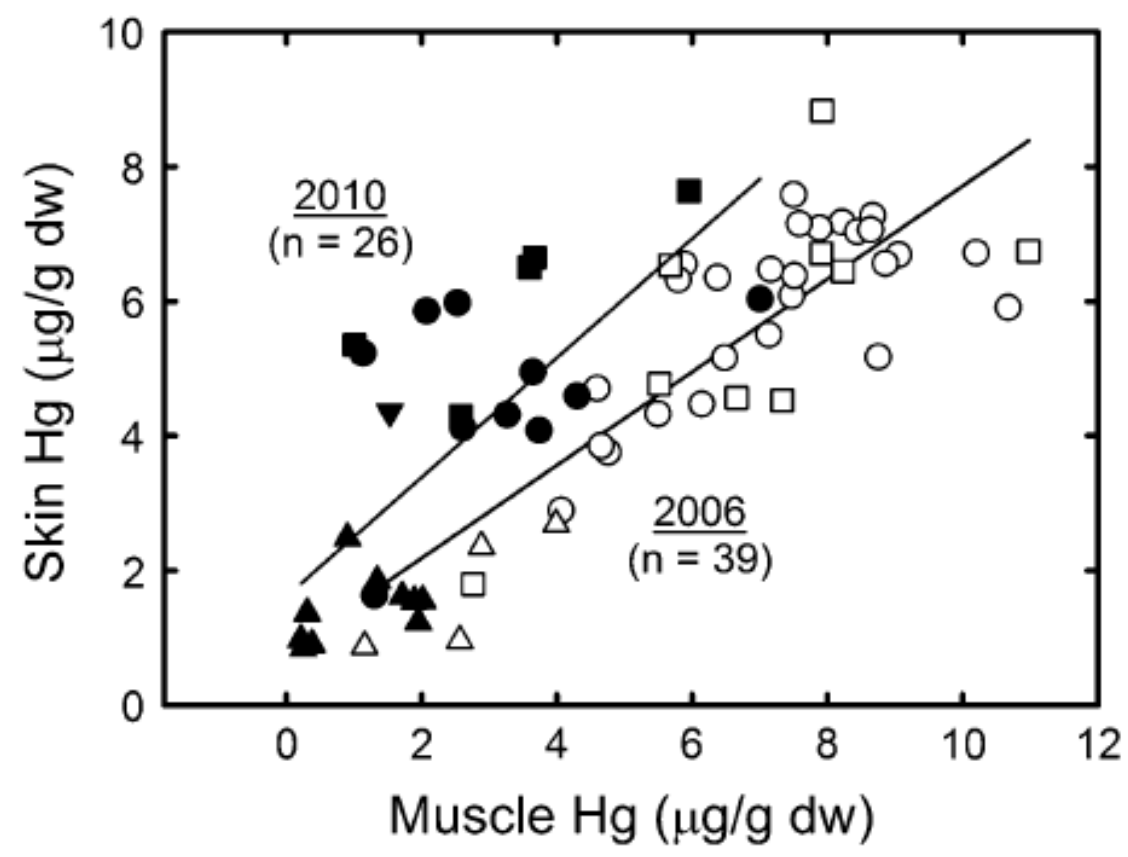

Figure 4. Relationship between skin and muscle $\mathrm{Hg}$ concentrations of calves (triangles up), females (circles), males (squares) and unsexed (triangle down) long-finned pilot whales that stranded in 2006 (white) and 2010 (black). Linear regressions: $y=0.69 x+0.80, r 2=0.68$, $F 1,37=78.36, p<0.0001$ and $y=0.89 x+1.62, r 2=0.50, F 1,24=23.90, p<0.0001$ in 2006 and 2010, respectively. 


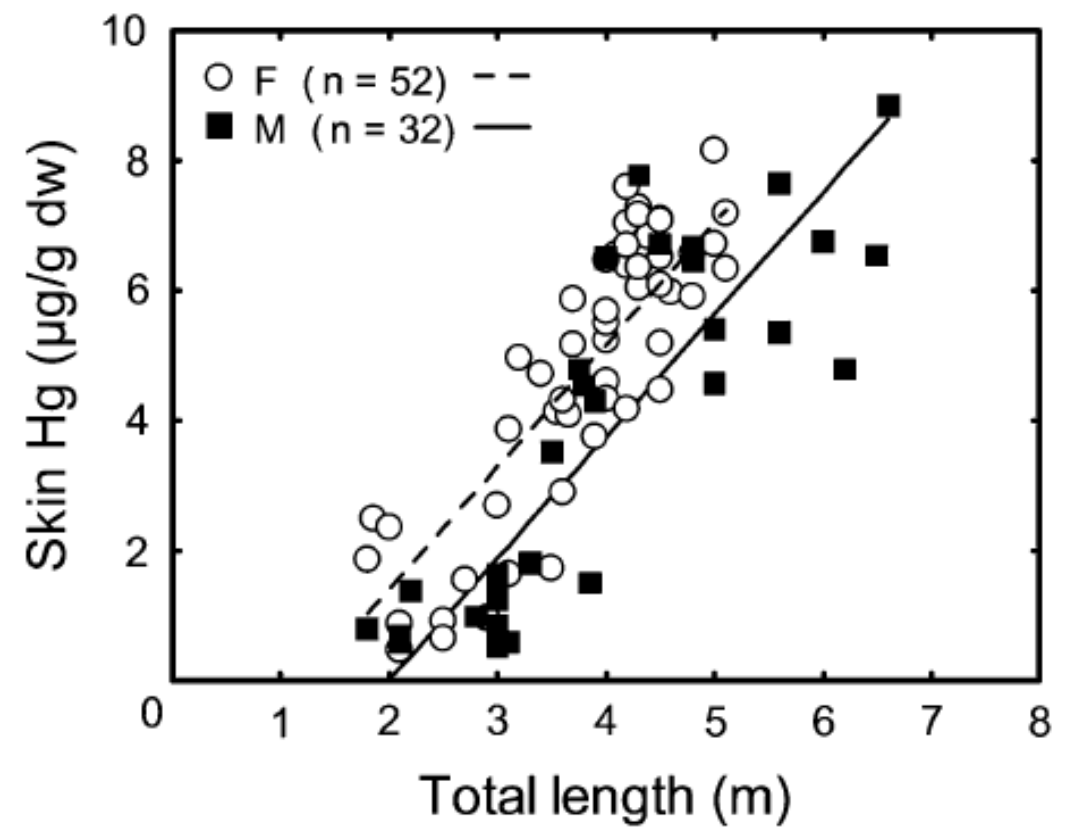

Figure 5. Relationship between skin $\mathrm{Hg}$ concentrations and total length of long-finned pilot whales (individuals from the two stranding events were pooled according to sexes and including calves). Best GLM model (Gaussian distribution, identity link function, $73 \%$ of explained variation): $y$ (females, white circles $)=1.88 x-2.34, y$ (males, black squares $)=1.88 x-3.75$ 
Table 1. Tissue $\delta^{13} \mathrm{C}, \delta^{15} \mathrm{~N}$ and $\mathrm{Hg}$ values in southern long-finned pilot whales from Kerguelen Islands. Values are mean $\pm \mathrm{SD}$ with ranges in parentheses. It was not possible to sex some individuals from the 2010 stranding event.

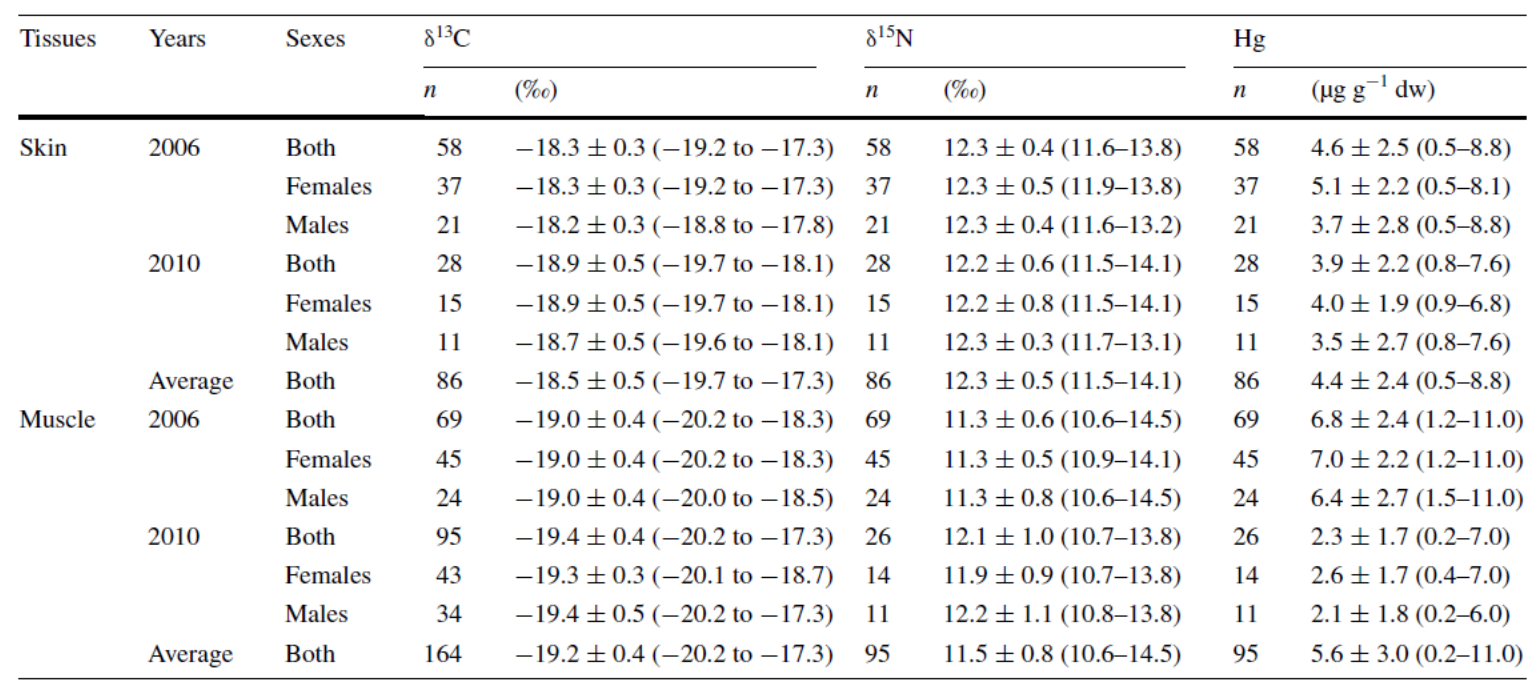


Table 2. Generalized linear models (Gaussian distribution, identity link function) selected for each tissue (skin: $\delta^{13} \mathrm{Cs}, \delta^{15} \mathrm{Ns}$, Hgs; muscle: $\delta^{13} \mathrm{Cm}, \delta^{15} \mathrm{Nm}, \mathrm{Hgm}$ ) with their corresponding AIC. AICc Akaike's Information Criteria adjusted for small sample sizes, Exp. Var. explained variation adjusted by sample size and number of parameters, $T L$ total length

\begin{tabular}{|c|c|c|c|}
\hline Response variable & Selected GLM & $\mathrm{AICc}$ & Exp. Var. (\%) \\
\hline \multicolumn{4}{|l|}{ Isotopes } \\
\hline \multicolumn{4}{|c|}{ Explanatory variables: size, year, sex } \\
\hline$\delta^{13} \mathrm{C}_{\mathrm{s}}$ & $\delta^{13} \mathrm{C}_{\mathrm{s}} \sim$ year & 48.80 & 30 \\
\hline$\delta^{13} \mathrm{C}_{\mathrm{m}}$ & $\delta^{13} \mathrm{C}_{\mathrm{m}} \sim$ year & 119.00 & 19 \\
\hline$\delta^{15} \mathrm{~N}_{\mathrm{s}}$ & $\delta^{15} \mathrm{~N}_{\mathrm{s}} \sim$ year $+\mathrm{TL}+$ sex & 53.58 & 19 \\
\hline$\delta^{15} \mathrm{~N}_{\mathrm{m}}$ & $\delta^{15} \mathrm{~N}_{\mathrm{m}} \sim$ year $+\mathrm{TL}$ & 155.91 & 28 \\
\hline \multicolumn{4}{|l|}{$\mathrm{Hg}$} \\
\hline \multicolumn{4}{|c|}{ Explanatory variables: size, year, sex, $\delta^{13} \mathrm{C}$} \\
\hline $\mathrm{Hg}_{\mathrm{s}}$ & $\mathrm{Hg}_{\mathrm{s}} \sim \mathrm{TL}+\mathrm{sex}$ & 282.56 & 73 \\
\hline $\mathrm{Hg}_{\mathrm{m}}$ & $\mathrm{Hg}_{\mathrm{m}} \sim \mathrm{TL}+$ sex + year $+\delta^{13} \mathrm{C}_{\mathrm{m}}+\mathrm{TL}: \delta^{13} \mathrm{C}_{\mathrm{m}}+$ sex: $\delta^{13} \mathrm{C}_{\mathrm{m}}+$ year $: \delta^{13} \mathrm{C}_{\mathrm{m}}+$ sex: size & 327.36 & 81 \\
\hline
\end{tabular}

Table 3. A review of skin and muscle $\delta^{13} \mathrm{C}, \delta^{15} \mathrm{~N}$ and $\mathrm{Hg}$ values in pilot whales 
Table 3. A review of skin and muscle $\delta^{13} \mathrm{C}, \delta^{15} \mathrm{~N}$ and $\mathrm{Hg}$ values in pilot whales. Values are mean $\pm \mathrm{SD} ; n m$ no measurements ; a Values are mean \pm SE; b Results were initially reported in wet weight and were converted here to dry weight using a factor of 0.285 (Dam and Bloch 2000)

\begin{tabular}{|c|c|c|c|c|c|c|c|c|c|c|c|}
\hline Tissue & Pilot whales & Location & $n$ & $\begin{array}{l}\text { Lipid extraction } \\
\text { or normalization }\end{array}$ & $\delta^{13} \mathrm{C}(\%)$ & $n$ & $8^{15} \mathrm{~N}(\%)$ & $n$ & $\begin{array}{l}\text { Total } \mathrm{Hg} \\
\left(\mu \mathrm{gg}^{-1} \text { ww }\right)\end{array}$ & $\begin{array}{l}\text { Total Hg } \\
\left(\mu \mathrm{g} \mathrm{g}^{-1} \mathrm{dw}\right)\end{array}$ & References \\
\hline \multirow[t]{9}{*}{ Skin } & $\begin{array}{l}\text { Southern } \\
\text { long-finned }\end{array}$ & Kerguelen & 86 & Extraction & $-18.5 \pm 0.5$ & 86 & $12.3 \pm 0.5$ & 86 & & $4.4 \pm 2.4$ & This study \\
\hline & $\begin{array}{l}\text { Northern } \\
\text { long-finned }\end{array}$ & Gibraltar & 51 & Extraction & $-16.4 \pm 0.4$ & 51 & $11.3 \pm 0.4$ & & & $\mathrm{~nm}$ & de Stephanis et al. (2008) \\
\hline & & Eastern USA & & & $\mathrm{nm}$ & 3 & $13.8 \pm 0.4$ & & & $\mathrm{~nm}$ & Abend and Smith (1995) \\
\hline & & & & & $\mathrm{nm}$ & 3 & $13.9 \pm 0.4$ & & & $\mathrm{~nm}$ & Abend and Smith (1995) \\
\hline & & & 6 & No & $-18.8 \pm 0.1^{2}$ & 6 & $13.9 \pm 0.1^{\mathrm{a}}$ & & & $\mathrm{nm}$ & Abend and Smith (1997) \\
\hline & & Faroe Islands & & & $\mathrm{nm}$ & 3 & $11.7 \pm 0.5$ & & & $\mathrm{~nm}$ & Abend and Smith (1995) \\
\hline & & Southern France & 5 & Normalization & $-17.5 \pm 0.7$ & 5 & $9.8 \pm 0.3$ & & & $\mathrm{~nm}$ & Praca et al. (2011) \\
\hline & & Corsica & & & $\mathrm{nm}$ & & $\mathrm{nm}$ & 1 & & 27.0 & Frodello et al. (2000) \\
\hline & Short-finned & Polynesia & 12 & Extraction & $-14.7 \pm 0.5$ & 12 & $15.2 \pm 0.7$ & & & $\mathrm{~nm}$ & Kiszka et al. (2010) \\
\hline \multirow[t]{26}{*}{ Muscle } & $\begin{array}{l}\text { Southern } \\
\text { long-finned }\end{array}$ & $\begin{array}{l}\text { Southern } \\
\text { Australia }\end{array}$ & 94 & No & $-19.6 \pm 0.4$ & 94 & $10.7 \pm 0.9$ & & & $\mathrm{~nm}$ & Davenport and Bax (2002) \\
\hline & & Kerguelen & 164 & Extraction & $-19.2 \pm 0.4$ & 95 & $11.5 \pm 0.8$ & 95 & & $5.6 \pm 3.0$ & This study \\
\hline & $\begin{array}{l}\text { Northern } \\
\text { long-finned }\end{array}$ & Eastern USA & & & $\mathrm{nm}$ & 3 & $13.2 \pm 0.1$ & & & $\mathrm{~nm}$ & Abend and Smith (1995) \\
\hline & & & & & $\mathrm{nm}$ & 3 & $13.4 \pm 0.2$ & & & $\mathrm{~nm}$ & Abend and Smith (1995) \\
\hline & & & 6 & No & $-18.0 \pm 0.1^{2}$ & 6 & $13.3 \pm 0.1^{\mathrm{a}}$ & & & $\mathrm{nm}$ & Abend and Smith (1997) \\
\hline & & Faroe Islands & & & $\mathrm{nm}$ & & $\mathrm{nm}$ & 31 & $1.4 \pm 1.8$ & $4.7^{\mathrm{b}}$ & Caurant et al. (1993) \\
\hline & & & & & $\mathrm{nm}$ & & $\mathrm{nm}$ & 50 & $0.4 \pm 0.4$ & $1.4^{\mathrm{b}}$ & Caurant et al. (1993) \\
\hline & & & & & $\mathrm{nm}$ & 3 & $11.5 \pm 0.5$ & & & $\mathrm{~nm}$ & Abend and Smith (1995) \\
\hline & & & & & $\mathrm{nm}$ & & $\mathrm{nm}$ & 15 & $1.8 \pm 0.5$ & $6.3^{\mathrm{b}}$ & Julshamn et al. (1987) \\
\hline & & & & & $\mathrm{nm}$ & & $\mathrm{nm}$ & 10 & $3.3 \pm 1.7$ & $11.6^{\mathrm{b}}$ & Julshamn et al. (1987) \\
\hline & & & & & $\mathrm{nm}$ & & $\mathrm{nm}$ & 33 & $2.7 \pm 0.2$ & $9.4^{\mathrm{b}}$ & Caurant et al. (1996) \\
\hline & & & & & $\mathrm{nm}$ & & $\mathrm{nm}$ & 417 & 1.9 & $6.6^{\mathrm{b}}$ & Dam and Bloch (2000) \\
\hline & & Bay of Biscay & 16 & Extraction & $-16.3 \pm 0.8$ & 16 & $13.2 \pm 1.8$ & & & $\mathrm{~nm}$ & Lassalle et al. (2014) \\
\hline & & Western Iberia & 9 & Extraction & $-16.5 \pm 0.5$ & 9 & $12.2 \pm 0.6$ & & & $\mathrm{~nm}$ & $\begin{array}{l}\text { Mendez-Fernandez et al. } \\
\quad(2012,2013)\end{array}$ \\
\hline & & Corsica & & & $\mathrm{nm}$ & & $\mathrm{nm}$ & 1 & & 25.0 & Frodello et al. (2000) \\
\hline & Short-finned & Japan & & & $\mathrm{nm}$ & & $\mathrm{nm}$ & 12 & $4.2 \pm 0.7$ & $14.6^{\mathrm{b}}$ & Arima and Nagakura (1979) \\
\hline & & & & & $\mathrm{nm}$ & & $\mathrm{nm}$ & 23 & $7.6 \pm 6.1$ & $26.6^{\mathrm{b}}$ & Endo et al. (2003) \\
\hline & & & & & $\mathrm{nm}$ & & $\mathrm{nm}$ & 4 & $5.4-13.8$ & $18.9-48.4^{\mathrm{b}}$ & Endo et al. (2004) \\
\hline & & Northern Japan & & & $\mathrm{nm}$ & & $\mathrm{nm}$ & 31 & $2.8 \pm 0.8$ & $9.8^{\mathrm{b}}$ & $\begin{array}{l}\text { Honda (1990) in Endo et al. } \\
(2005)\end{array}$ \\
\hline & & & & & $\mathrm{nm}$ & & $\mathrm{nm}$ & 8 & $1.5 \pm 0.5$ & $5.3^{\mathrm{b}}$ & Endo et al. (2005) \\
\hline & & & 5 & Extraction & $-18.3 \pm 0.6$ & 5 & $13.3 \pm 0.8$ & 5 & $1.3 \pm 0.4$ & $4.6^{\mathrm{b}}$ & Endo et al. (2010) \\
\hline & & Southern Japan & & & $\mathrm{nm}$ & & $\mathrm{nm}$ & 4 & $7.1 \pm 1.9$ & $24.9^{\mathrm{b}}$ & $\begin{array}{l}\text { Anonymous (2003) in } \\
\text { Endo et al. (2005) }\end{array}$ \\
\hline & & & & & $\mathrm{nm}$ & & $\mathrm{nm}$ & 34 & $11.6 \pm 8.2$ & $40.7^{\mathrm{b}}$ & Endo et al. (2005) \\
\hline & & & 18 & Extraction & $-16.5 \pm 0.5$ & 18 & $12.2 \pm 0.6$ & 18 & $12.4 \pm 8.6$ & $43.5^{\mathrm{b}}$ & Endo et al. (2010) \\
\hline & & New Caledonia & & & $\mathrm{nm}$ & & $\mathrm{nm}$ & 2 & & $27.3-32.8$ & Bustamante et al. (2003b) \\
\hline & & Lesser Antilles & & & $\mathrm{nm}$ & & $\mathrm{nm}$ & 5 & $4.0 \pm 0.9$ & $14.0^{\mathrm{b}}$ & Gaskin et al. (1974) \\
\hline
\end{tabular}

